\title{
A paleomagnetic record of the early Matuyama chron including the Réunion subchron and the onset Olduvai boundary: High-resolution magnetostratigraphy and insights from transitional geomagnetic fields
}

\author{
Takumi Konishi $^{1}$ and Makoto Okada ${ }^{2^{*}}$ (D)
}

\begin{abstract}
We present a novel paleomagnetic record for the lower Matuyama chronozone, which includes the Réunion subchronozone and the lower Olduvai polarity reversal, from a continuous section of a 168-m-thick on-land marine succession in the southernmost part of the Boso Peninsula, central Japan. In this section, the Réunion subchronozone and the lower Olduvai reversal are observed at 38.6-44.6 $\mathrm{m}$ and $142.0 \mathrm{~m}$, respectively. The average sedimentation rates between the lower and upper Réunion boundaries and between the upper Réunion boundary and lower Olduvai boundary are calculated as $25 \mathrm{~cm} / \mathrm{ky}$ and $57 \mathrm{~cm} / \mathrm{ky}$, respectively. The virtual geomagnetic pole (VGP), observed in the Boso Peninsula, at both the upper and lower Réunion boundaries passed across the equator within a similar longitudinal band over Africa. Immediately below the upper boundary, between 43.0 and $43.5 \mathrm{~m}$, the VGP settled in a cluster area around China. Relative paleointensity (RPI) values for the entire Réunion interval are generally lower than the average for the entire interval from the Réunion to the lower Olduvai subchronozone. Conversely, the VGP for the lower Olduvai reversal boundary did not pass across the equator within a narrow longitudinal band but settled in several cluster areas; i.e., the southern Indian Ocean, North America, and the southern South Pacific Ocean off South America. The VGP then moved rapidly between the clusters. The locations of VGP cluster areas in the lower Olduvai reversal seem to coincide with areas where a vertical component of the present geomagnetic non-axial dipole (NAD) field is dominant. During the reversal, the RPI declined rapidly and recovered slowly as the VGP moved rapidly between cluster areas. Our new paleomagnetic data are one of the most detailed records for those geomagnetic reversals from marine sediments, and will, therefore, help to understand the dynamics of the geomagnetic reversals.
\end{abstract}

Keywords: Paleomagnetism, Rock-magnetism, Geomagnetic reversals, Lower Olduvai reversal, Réunion subchron, Relative paleointensity, Boso Peninsula

\footnotetext{
* Correspondence: makoto.okada.sci@vc.ibaraki.ac.jp

2Department of Earth Sciences, Ibaraki University, 2-2-1 Bunkyo, Mito, Ibaraki

310-8512, Japan

Full list of author information is available at the end of the article
}

\section{Springer Open}

(0) The Author(s). 2020 Open Access This article is licensed under a Creative Commons Attribution 4.0 International License, which permits use, sharing, adaptation, distribution and reproduction in any medium or format, as long as you give appropriate credit to the original author(s) and the source, provide a link to the Creative Commons licence, and indicate if changes were made. The images or other third party material in this article are included in the article's Creative Commons licence, unless indicated otherwise in a credit line to the material. If material is not included in the article's Creative Commons licence and your intended use is not permitted by statutory regulation or exceeds the permitted use, you will need to obtain permission directly from the copyright holder. To view a copy of this licence, visit http://creativecommons.org/licenses/by/4.0/. 


\section{Introduction}

Geomagnetic reversals are one of the most significant fluctuations in the Earth's magnetic field, during which the magnetic intensity decreases by an order of magnitude as the polarity transitions (e.g., Merrill and McFadden 1999; Valet and Fournier 2016). Moreover, studies based on several high-resolution reversal records suggest that the behavior of the geomagnetic field during polarity transitions could be related to the present non-axial dipole (NAD) field (e.g., Channell et al. 2003, 2004; Hoffman et al. 2008). Therefore, determining the behavior of the magnetic field during a geomagnetic reversal could be the key to revealing the mechanisms governing geomagnetic field generation and outer core dynamics (e.g., Ingham and Turner 2008; Amit et al. 2010). Hoffman (1992) attempted to determine the characteristics of geomagnetic variations during reversals using paleomagnetic records from lava flow sequences around the world. Although paleomagnetic records from volcanic rocks, such as lava flows, can provide stable magnetic signals associated with the absolute intensity of past geomagnetic fields, the resulting records are intermittent because volcanic eruptions do not occur continuously (e.g., Jarboe et al. 2011; Valet et al. 2012).

Conversely, despite only recording relative and not absolute magnetic intensities, sedimentary paleomagnetic records reveal continuous geomagnetic field variations, including geomagnetic reversals (e.g., Channell 2017; Valet and Fournier 2016). Previous sedimentary records reconstructing long-term variations in the geomagnetic dipole moment have successfully revealed the general features of geomagnetic dipole fluctuations (e.g., Valet et al. 2005; Yamazaki and Oda 2005; Channell et al. 2009). However, the details of paleointensity variations during polarity transitions are often not recorded in standard deep-sea cores because the sedimentation rates are generally relatively low, i.e., approximately a few centimeters per thousand years. Such a low sedimentation rate prevents the accurate recording of rapid geomagnetic variations due to the smoothing of the magnetic signal associated with the post-depositional remanent magnetization (pDRM) process (e.g., Roberts and Winklhofer 2004; Suganuma et al. 2011; Valet et al. 2016). Therefore, for a more detailed description of geomagnetic field characteristics during polarity transitions, on-land marine successions with sufficiently high sedimentation rates, such as reported by Okada et al. (2017) and Simon et al. (2019), are crucial.

The Kazusa Group, a forearc basin-fill deposit formed from the Calabrian to the early Chibanian age, is widely distributed in the central part of the Boso Peninsula (e.g., Kazaoka et al. 2015) (Fig. 1b, c). Due to good exposure of the geologic strata, the biostratigraphy, magnetostratigraphy, and oxygen isotope stratigraphy of the Kazusa Group have been comprehensively studied (e.g., Niitsuma 1971; Oda 1977; Niitsuma 1976; Okada and Niitsuma 1989). In recent years, many chronostratigraphic studies have been conducted for the upper part of the Kazusa Group (Kazaoka et al. 2015; Suganuma et al. 2015; Nishida et al. 2016; Okada et al. 2017; Suganuma et al. 2018; Simon et al. 2019; Haneda et al. 2020). As well as the Kazusa Group, the middle Miocene-upper Pliocene Awa Group, distributed in the middle part of the Boso Peninsula, has been well documented using magnetostratigraphy (Niitsuma 1976), and magnetic and oxygen isotope stratigraphy (Haneda and Okada 2019) (Fig. 1b, c).

In contrast, the Chikura Group, a small basin-fill deposit on the trench slope in the southernmost part of the Boso Peninsula formed during the Piacenzian to early Calabrian (Kotake 1988; Kotake et al. 1995; Kawakami and Shishikura 2006) (Fig. 1c), exhibits complex geology and developed folds and faults (see Fig. $1 \mathrm{~d}$ ). As a result, the construction of a continuous chronostratigraphic record has been hindered for a long time. However, Okada et al. (2012) established the paleomagneticoxygen isotopic stratigraphy between 3.15 and $2.35 \mathrm{Ma}$ in the Chikura Group by selecting suitable routes for recovering a continuous stratigraphic record (see Fig. 1c, e)

In this study, we aim to provide a paleomagnetic record during the early Matuyama chron, which includes the Réunion subchron and the onset Olduvai boundary where the previous study was not conducted, through the establishment of the detailed magnetostratigraphy of the upper part of the Chikura Group. Oxygen isotopic analysis of fossil foraminiferal tests from this succession is ongoing; therefore, this will be reported elsewhere. Note that the Réunion subchron used in this study is the same one that has been redefined as "Feni" subchron by Channell et al. (2020).

\section{Geologic setting}

The Boso Peninsula is located on the Pacific side of central Japan, close to the trench-trench-trench type triple junction (Fig. 1a). The southernmost part of the Boso Peninsula contains sediments deposited in deep-sea trench and trench-slope basins; this sedimentary sequence was named as the Chikura Group (Naruse et al. 1951; Kotake 1988) (Fig. 1b). The central part of the Chikura Group consists of, in ascending order, the Shirahama, Shiramazu, Mera, Minamiasai, and Hata Formations, in which the sediments are predominantly siltstone, sandy siltstone, and alternating sandstone and siltstone layers, with frequently intercalated tephra beds (Kotake 1988). Kotake et al. (1995) reconstructed the chronostratigraphy of the Chikura Group based on a detailed field survey and a paleomagnetic study. They also revealed that the Matuyama-Gauss boundary is contained in the Minamiasai Formation (Fig. 1e). By conducting a detailed correlation of the tephra beds, Kawakami and Shishikura (2006) redefined parts of the 

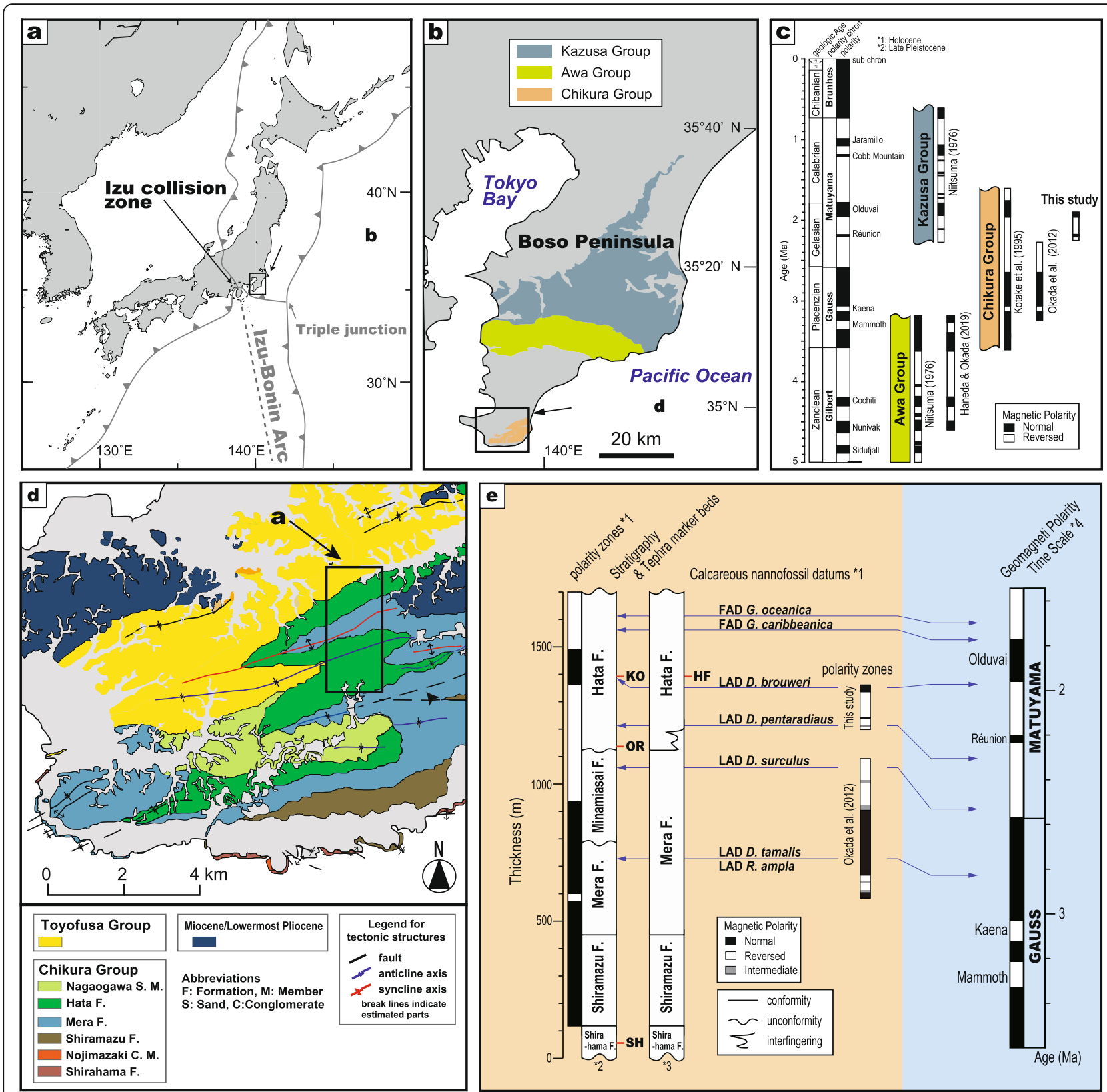

Fig. 1 Location map of this study sites. a Location of the Japanese archipelago. The tectonic setting is drawn after Tatsumi et al. (2016). b Distribution of the Awa Group, the Chikura Group, and the Kazusa Group, which are Miocene-Pleistocene marine successions on the Boso Peninsula based on Mitsunashi and Suda (1980), Unozawa et al. (1983), and Kawakami and Shishikura (2006). c Chronological positions for the last 5 Ma of the Awa Group, the Chikura, and the Kazusa Group associated with the magnetostratigraphy. $\mathbf{d}$ Geologic map of the southernmost part of the Boso Peninsula, modified from Kawakami and Shishikura (2006). e Stratigraphic correlation of the Chikura Group associated with the magnetostratigraphy and the calcareous nannofossil datums. *1 Kotake et al. (1995), *2 Kotake (1988), *3 Kawakami and Shishikura (2006), *4 Ogg (2012)

Chikura Group, namely that the Minamiasai Formation is a part of the Mera Formation and the Mera Formation is partly inter-fingered with the Hata Formation (Fig. $1 \mathrm{e})$. However, since most of the previous chronostratigraphic studies conducted on the Chikura Group (e.g., Kotake et al. 1995; Okada et al. 2012; Tamura et al. 2016; Kameo and Okada 2016) have followed the stratigraphic classification by Kotake (1988), we use the Hata
Formation defined by Kotake (1988) to keep consistency with the previous studies.

\section{Methods/Experimental}

Collection of paleomagnetic core samples

We conducted a geologic survey and collected paleomagnetic mini-core samples from the lower to the middle part of the Hata Formation that is exposed along a route consisting of a 


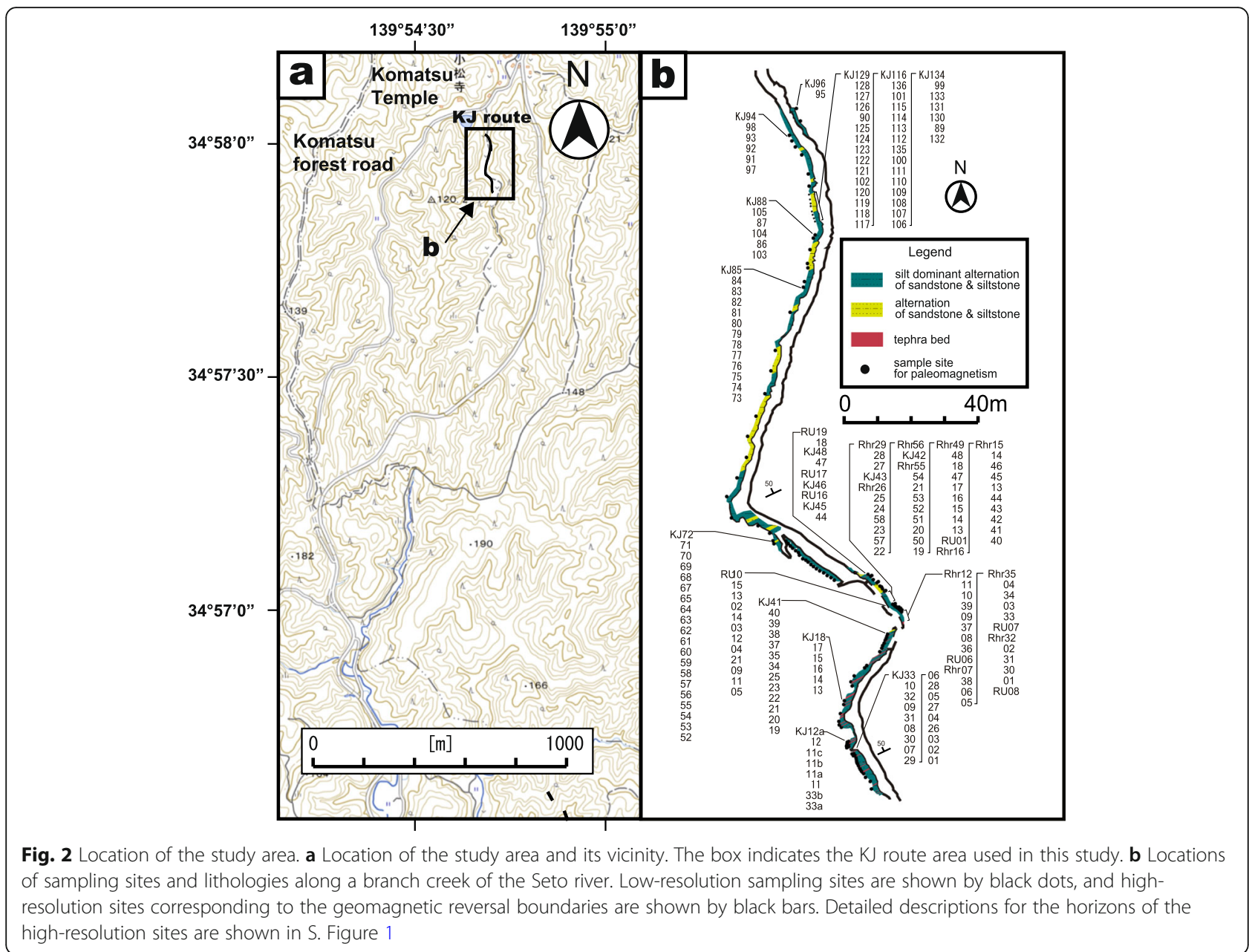

small creek running to near Komatsu-ji (Komatsu Temple), Chikura town, Minamiboso City, in the southernmost part of the Boso Peninsula (Fig. 2a, b). We named this route as the "KJ route" $\left(34.9668^{\circ} \mathrm{N}, 139.9114^{\circ} \mathrm{E}-34.9649^{\circ} \mathrm{N}, 139.9117^{\circ}\right.$ E). This part of the Hata Formation contains the last appearance horizon of Discoaster brouweri, which is a calcareous nannoplankton indicating a horizon just below the Olduvai subchronozone (Sato et al. 1988), and a normal polarity zone above the datum horizon (Kotake et al. 1995) (Fig. 1e). The KJ route follows a small creek, which is a branch of the Seto River that runs beside the Komatsu Temple along the Komatsu forest road (Fig. 2 a). In this study, we described a continuous section along the KJ route measuring $168 \mathrm{~m}$ thick (Fig. $2 \mathrm{~b}$ and S.Fig. 1).

From the KJ route, we collected 25 -mm-diameter drilled core samples for rock-magnetic and paleomagnetic measurements using a portable engine drill. The cores were collected from 218 horizons, typically at intervals of 1-4 m; however, intervals of less than $10 \mathrm{~cm}$ were employed around the magnetozone boundaries assigned with the lower Olduvai and upper and lower Réunion boundaries.
At each horizon, we collected more than three pieces of core. The drilled core samples were oriented with a magnetic compass before being extracted from the holes. The collected core samples were cut into 2-cm-long specimens for subsequent measurements.

\section{Paleomagnetic measurements}

The natural remanent magnetization (NRM) of each specimen was measured using a two-axis cryogenic magnetometer (SRM-750R; 2G Enterprises, USA) in a magnetic shield room at Ibaraki University. To extract the primary magnetic component, which was acquired when the sample rock was formed, we removed the secondary remanence from the NRM by conducting three types of treatment: progressive alternating field demagnetization (pAFD), progressive thermal demagnetization $(\mathrm{pThD})$, and a hybrid method that is a combination of thermal demagnetization at $250{ }^{\circ} \mathrm{C}$ and subsequent pAFD. To minimize the thermal alternation of specimens, the minimum temperature to which the secondary components are effectively removed was selected as the appropriate temperature. The hybrid 
method was used in Okada et al. (2017), in which $300{ }^{\circ} \mathrm{C}$ was chosen as the appropriate temperature, whereas $250{ }^{\circ} \mathrm{C}$ was used in this study. Alternating field and thermal demagnetization treatments were conducted at Ibaraki University using an alternating field demagnetizer (DEM-8601; Natsuhara-Giken, Japan) and a thermal demagnetizer (TD48; ASC Scientific, USA), respectively. The pAFD treatment was performed up to $80 \mathrm{mT}$ every $5 \mathrm{mT}$ for 45 specimens from 45 horizons and the pThD from $150-600{ }^{\circ} \mathrm{C}$ every 50 ${ }^{\circ} \mathrm{C}$ for 77 specimens from 77 horizons. The hybrid treatment, performed for 216 specimens from 154 horizons, was applied to remove the secondary remanence, which holds a similar or higher coercive force, but a lower unblocking temperature than the primary remanence.

We extracted the characteristic remanent magnetization (ChRM) using more than five remanent vector endpoints, which were aligned linearly toward the origin, by principal component analysis (Kirschvink 1980). In the pAFD and pThD treatments, the data points used to deduce ChRMs were selected from appropriate demagnetization intervals at each specimen. In contrast, for the hybrid treatment, the data points were from the demagnetization interval between 20 and $50 \mathrm{mT}$ for all the specimens. The virtual geomagnetic pole (VGP) at each sampling site was calculated from a site-mean direction obtained from multiple ChRM directions when multiple ChRMs at a site were available. However, if the only single ChRM was available at a site, the VGP was calculated from a single ChRM. In any case, the VGPs were deduced from the ChRMs whose maximum angular deviations (MADs) were equal to or less than $15^{\circ}$. We identified the magnetic polarities based on VGP latitudes, where latitudes of greater than $+45^{\circ}$ are defined as normal polarity, latitudes of less than $-45^{\circ}$ are defined as reversed polarity, and latitudes of less than the absolute value of $45^{\circ}$ are defined as intermediate polarity.

Proxies of magnetic grain concentration; i.e., $k_{\mathrm{LF}}$, anhysteretic remanent magnetization (ARM), and isothermal remanent magnetization (IRM), are typically employed to normalize NRM when calculating the relative paleointensity (RPI) index (e.g., Valet 2003; Suganuma et al. 2008). Following the methodology of Okada et al. (2017), we calculated the NRM30-50/ARM30-50 ratio as the RPI index; i.e., NRM30-50 and ARM30-50 are coercivity fractions between 30 and $50 \mathrm{mT}$ for the NRM and ARM after thermal demagnetization at the appropriate temperature $\left(250^{\circ} \mathrm{C}\right)$ used in the hybrid demagnetization method.

\section{Rock-magnetic measurements}

To evaluate the magnetic properties (magnetic grain concentration, magnetic grain size, domain state of magnetic grains, magnetic carrier minerals) of samples from the KJ route, we performed the following rock-magnetic experiments. Before any other paleomagnetic and rock-magnetic measurements were performed, we measured the low- field magnetic susceptibility $\left(k_{\mathrm{LF}}\right)$ of each specimen using a Kappabridge susceptibility meter (KLY-3S; AGICO, Czech Republic) at Ibaraki University. The anhysteretic remanent magnetization (ARM) was applied for specimens in a $0.03-\mathrm{mT}$ DC field with an $80-\mathrm{mT}$ alternating field using the DEM 8601 demagnetizer at Ibaraki University. The ARM susceptibility $\left(k_{\mathrm{ARM}}\right)$ was calculated from the initial intensity of ARM. These magnetic susceptibilities represent magnetic grain concentration. The $k_{\mathrm{ARM}} /$ $k_{\mathrm{LF}}$ ratio could be used as a proxy for the magnetic grain size only under certain conditions, including a constant concentration of magnetic grains (e.g., Yamazaki and Ioka 1997). Although, we exhibit the ratio as a reference for the magnetic grain size due to that the variations of both concentration proxies $\left(k_{\mathrm{ARM}}\right.$ and $\left.k_{\mathrm{LF}}\right)$ are well within an order of magnitude in this study (Fig. 5a).

Magnetic hysteresis was measured with a maximum magnetic field of $1.0 \mathrm{~T}$ for selected specimens using an alternating gradient magnetometer (PMC MicroMag 2900 AGM; Lake Shore Cryogenics Inc., USA) at the Center for Advanced Marine Core Research, Kochi University (KCC). By using both the ratios of saturation remanence to saturation magnetization $(\mathrm{Mrs} / \mathrm{Ms})$ and coercivity of remanence to coercivity $(\mathrm{Hcr} / \mathrm{Hc})$ deduced from a hysteresis curve, a Day diagram (Day et al. 1977) was generated to illustrate the broad distribution of the magnetic domain states of ferrimagnetic particles.

Thermomagnetic experiments were performed using a thermomagnetic balance (NMB-89; Natsuhara Giken, Japan) at the KCC. The specimens were heated to $700{ }^{\circ} \mathrm{C}$ then cooled to room temperature in air or a vacuum in an applied field of $0.3 \mathrm{~T}$. The J-T curves obtained by these experiments allowed us to infer the magnetic minerals present in the specimens based on their Curie/Néel temperatures, blocking temperatures, and temperatures of thermal alteration. Low-temperature magnetic experiments were performed using a low-temperature SQUID magnetometer (MPMS XL-5; Quantum Design, USA) at the KCC. The specimens were magnetized in a 1-T field and warmed to $300 \mathrm{~K}$ after cooling to $10 \mathrm{~K}$ in a zero-T field. These experiments reveal the magnetic phase transition temperatures of the magnetic minerals included in a specimen without alteration due to heating and/or oxidation.

\section{Results and discussion}

\section{Rock-magnetic characteristics}

The results of the thermomagnetic and low-temperature magnetic analyses of the two selected specimens are shown in Fig. 3. The thermomagnetic experiments, performed in both air and a vacuum, demonstrate that the specimens have a single Curie/Néel temperature at approximately 580 ${ }^{\circ} \mathrm{C}$ (Fig. 3a). The thermomagnetic curve for specimen KJ100 shows no abrupt changes throughout the heating and cooling processes, but specimen Rhr44 exhibits a small plateau 
at approximately $450{ }^{\circ} \mathrm{C}$ during the heating process. The normalized induced magnetization $(\mathrm{J} / \mathrm{J} 0)$ during cooling in air is slightly smaller than that during heating for both specimens. In contrast, $\mathrm{J} / \mathrm{J} 0$ during cooling in a vacuum is slightly larger for KJ100 but substantially larger than that during heating for Rhr44 (Fig. 3a). The results of KJ100 indicate that the specimen contains (titano) magnetite with a Curie temperature close to that of magnetite at $585^{\circ} \mathrm{C}$ (e.g., Hunt et al. 1995). The cooling curves are irreversible because of the degradation of iron oxyhydroxides within the specimens into ferrimagnetic minerals due to the heating or minor thermal alteration of titanomagnetite (Bowles et al. 2013).

Conversely, the results of Rhr44, in which the specimen was heated in air, exhibit a small plateau at approximately $450{ }^{\circ} \mathrm{C}$, indicating the creation of a ferromagnetic mineral phase. The thermomagnetic curve of the cooling process in air has a lower magnetization than the equivalent heating curve, indicating that the ferromagnetic or ferrimagnetic minerals created at approximately $450{ }^{\circ} \mathrm{C}$ were further altered by continued heating and oxidized to form a higher Curie/Néel temperature mineral, such as hematite. In contrast, the specimen heated in a vacuum has a single Curie/Néel temperature at $580{ }^{\circ} \mathrm{C}$, the same as that heated in air, but almost no increase in magnetization at approximately $450{ }^{\circ} \mathrm{C}$. Moreover, unlike during the heating process, the curve exhibits a drastic increase in magnetization throughout the cooling process. The thermomagnetic behavior seen in Rhr44 was also observed in the Kazusa Group (Okada et al. 2017) and has been reported as one of the typical behaviors of greigitebearing samples (Roberts et al. 2011).

The low-temperature remanence curves (Fig. 3b) indicate the presence of a Verwey transition, where the magnetite transforms from a monoclinic to cubic spinel structure between 110 and $120 \mathrm{~K}$ (Verwey 1939; Özdemir et al. 1993). The curves, which indicate a declining ratio of magnetization per unit temperature, are characterized by a rapid remanence decline from 10 to $50 \mathrm{~K}$, with a broad Verwey transition from 100 to $120 \mathrm{~K}$. Özdemir et al. (1993) reported that the Verwey transition tends to shift to lower temperatures with a broader transition temperature range due to maghemitization (oxidation) on the surface of magnetite. The rapid decrease in remanence between 10 and $50 \mathrm{~K}$ is considered to be due to the influence of superparamagnetic particles (Özdemir et al. 1993; Özdemir and Dunlop 2010). The Day diagram of selected specimens is shown in Fig. 4. The boundaries of the magnetic domain state regions for the Day diagram follow the work of Dunlop (2002). All specimens fall into the vortex state (PSD) region (Roberts et al. 2017), which can also be interpreted as a mixture of particles in the SD and MD states, within a relatively small area where the data are distributed.
Although, as Roberts et al. (2018) recently discussed, the Day diagram is fundamentally ambiguous for domain state diagnosis; therefore, our diagnosis described above should be treated as just a reference for the domain states.

To evaluate the variation in rock-magnetic properties, the low-field magnetic susceptibility $\left(k_{\mathrm{LF}}\right)$ and the ARM susceptibility $\left(k_{\mathrm{ARM}}\right)$, as well as the ratio of both parameters throughout the stratigraphic sequence, are shown in Fig. 5a, b. As the ARM experiment was only conducted for the upper part above $36 \mathrm{~m}$, i.e., where the hybrid method was applied, the $\mathrm{k}_{\mathrm{ARM}}$ and the $\mathrm{k}_{\mathrm{ARM}} / \mathrm{k}_{\mathrm{LF}}$ ratio are not plotted below $36 \mathrm{~m}$. Although several spikes are observed in the $\mathrm{k}_{\mathrm{ARM}} / \mathrm{k}_{\mathrm{LF}}$ ratio, which likely corresponds to tephra and/or sandy layers, these data indicate that the rock-magnetic characteristics are relatively homogeneous for this interval (Fig. 5b). The $k_{\mathrm{LF}}$ and $k_{\mathrm{ARM}}$ curves, which exhibit variations well within an order of magnitude, suggest that the specimens from the KJ route are suitable for estimating RPIs (Tauxe 1993).

\section{Remanent magnetization}

Typical orthogonal vector diagrams (Zijderveld 1967) for the NRMs obtained from pAFD, pThD, and the hybrid method are shown in Fig. 6. The results of the pAFD (Fig. 6a, d) indicate that the NRMs consist of two magnetic components. The low-coercivity (LC) components were removed at a peak field of $15-20 \mathrm{mT}$ and the remaining high-coercivity $(\mathrm{HC})$ remanences demagnetized almost linearly, but slightly curvilinearly toward the origin (grey arrows in Fig. 6a, d). The demagnetization paths for the pThD (Fig. 6b, e) also indicate the existence of two components, among which the lowtemperature (LT) components are demagnetized by $250{ }^{\circ} \mathrm{C}$. The remaining high-temperature (HT) component of KJ85 (Fig. 6b) is almost linearly demagnetized toward the origin but slightly digresses at $600{ }^{\circ} \mathrm{C}$, whereas that of KJ82 (Fig. 6f) demagnetized with a curvilinear path (green arrows in Fig. $6 \mathrm{~b}, \mathrm{e}$ ), indicating that the HT component in KJ82 consists of a mixture of two different components. One of those components in HT had the same direction with LT but might have had blocking temperatures overlapped with the other component in HT. Moreover, the demagnetization path digresses substantially from $450{ }^{\circ} \mathrm{C}$ (red arrow in Fig. 6e), probably affected by magnetic minerals newly created during the $\mathrm{ThD}$ process. Although the secondary components seem to be removed more from the pThD paths than from the pAFD paths, the HT component in pThD may not be a primary component (Fig. 6e). In contrast, the hybrid results (Fig. 6c, f) for both specimens indicate that the secondary components are effectively removed by $15-20 \mathrm{mT}$ of AFD after $250{ }^{\circ} \mathrm{C}$ of $\mathrm{ThD}$ with no curvilinear demagnetization paths (orange arrow in Fig. 6f). Here, we assume that both the LC component and HC component in pAFD consist of a low unblocking temperature component and a high unblocking 
(a) Thermomagnetization
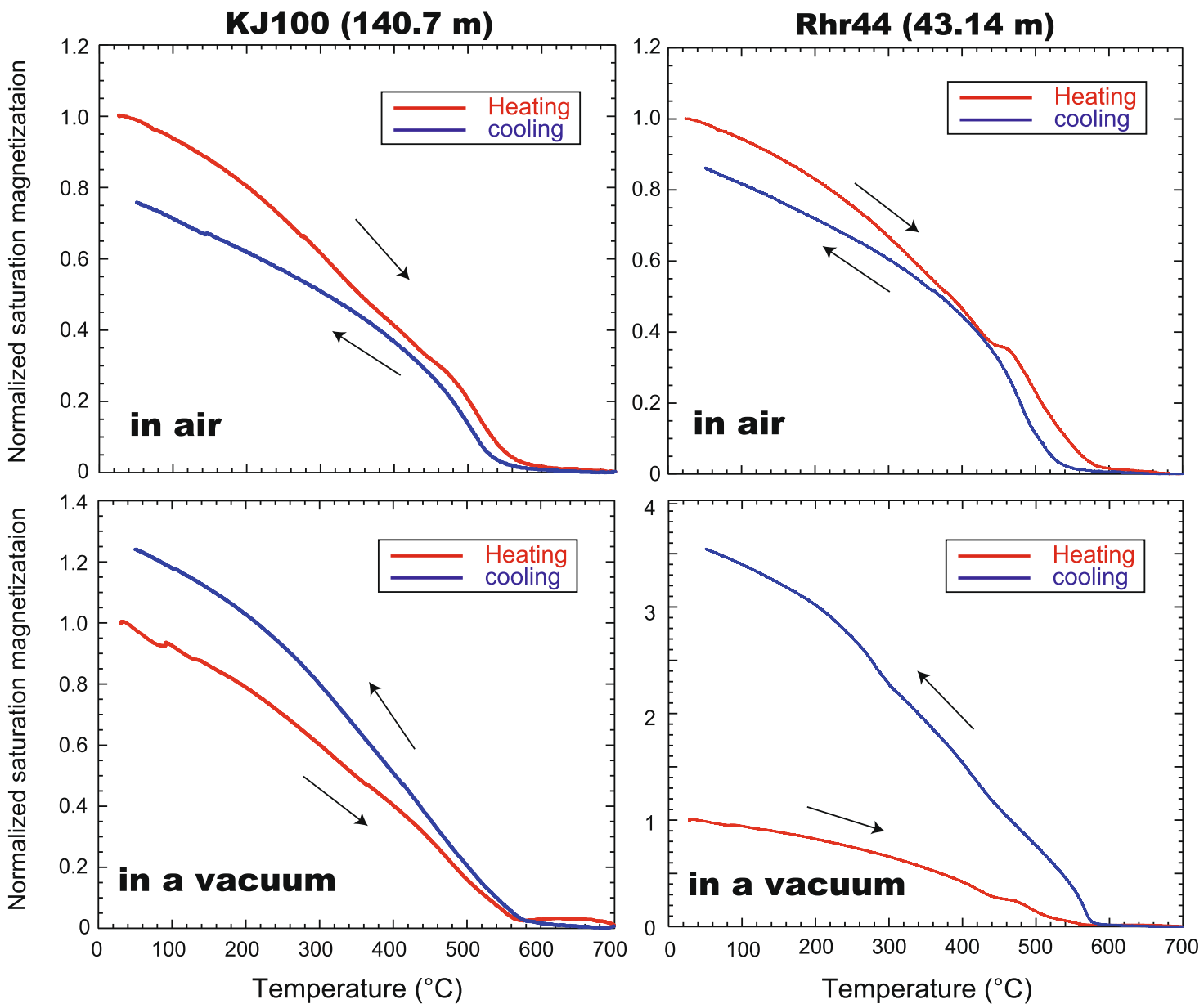

(b) Low-temperature magnetization
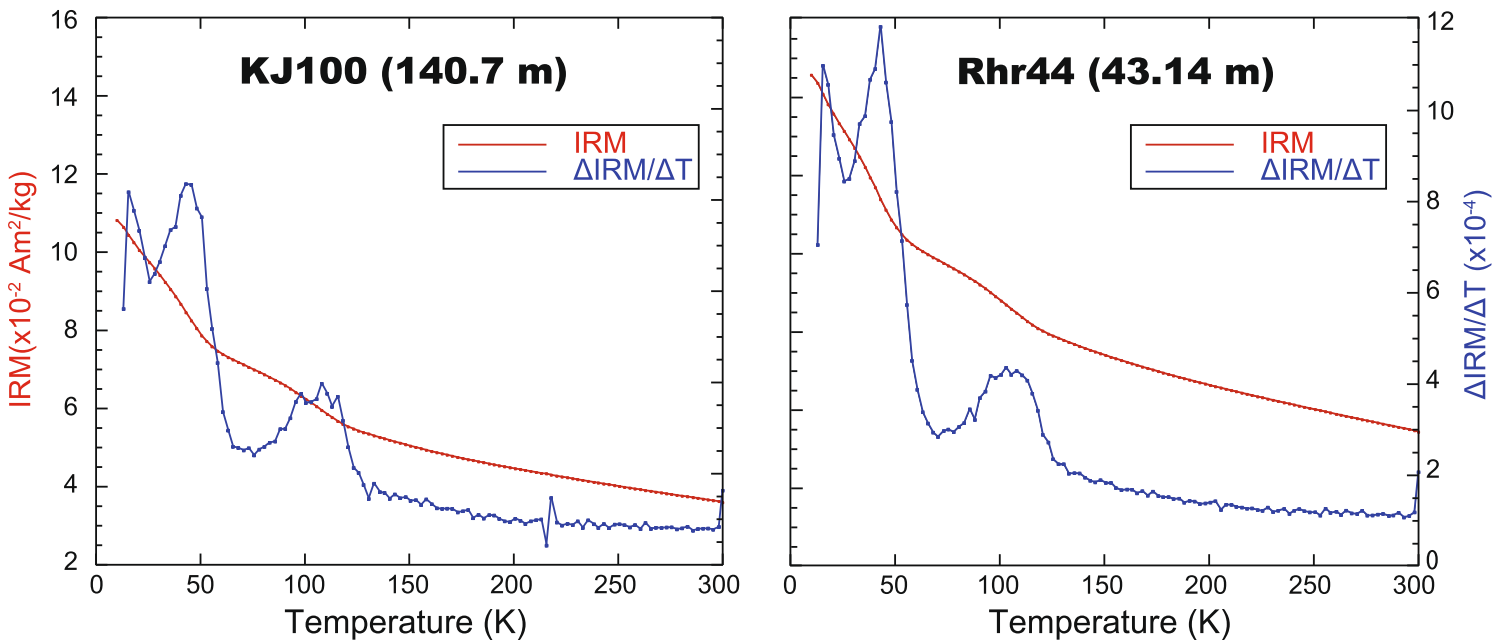

Fig. 3 Typical results of thermomagnetic and low-temperature magnetic experiments. a Results of thermomagnetic experiments. Left (right) diagrams indicate results from specimen KJ100 (Rhr44). Upper (lower) diagrams indicate results in air (a vacuum). b Results of low-temperature experiments. The left (right) diagram indicates results from specimen KJ100 (Rhr44) 


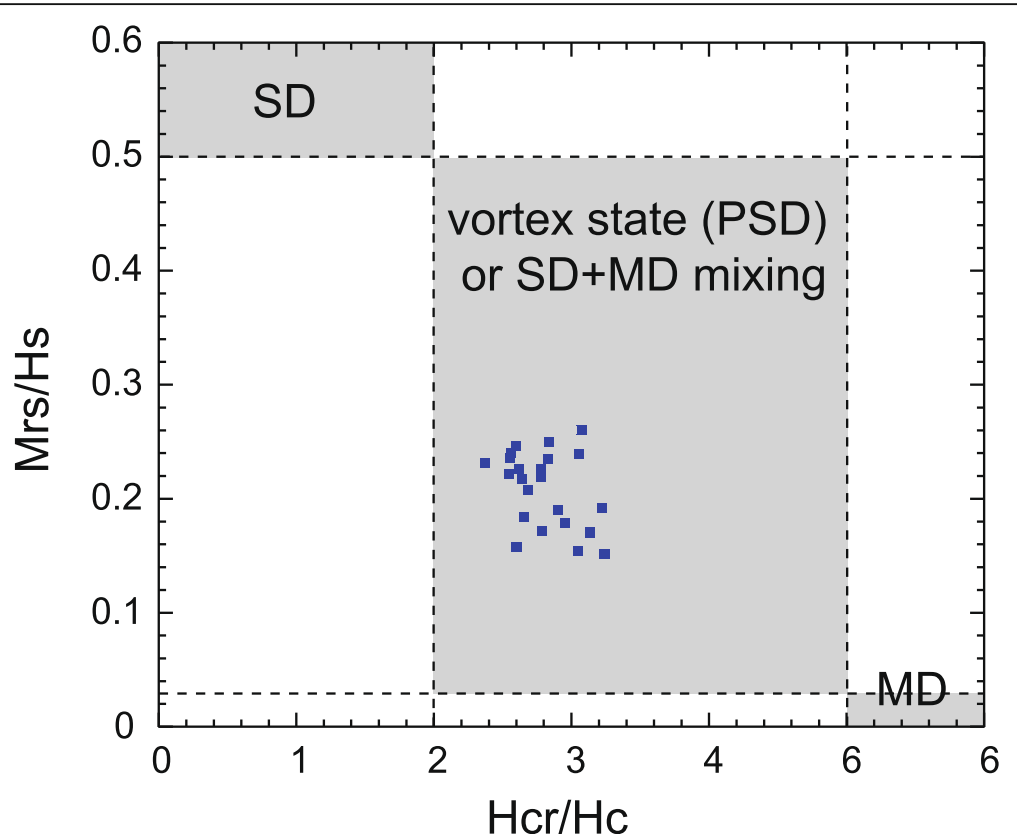

Fig. 4 Rock-magnetic results. Day diagram of hysteresis parameters from selected specimens. SD single domain, PSD pseudo-single domain, MD multi-domain. Domain state boundaries are drawn after Dunlop (2002)

temperature component, respectively. We can express the low and the high unblocking temperature component in the $\mathrm{LC}$ as ${ }_{\mathrm{L}} \mathrm{T}_{\mathrm{L}} \mathrm{C}$ and ${ }_{\mathrm{H}} \mathrm{T}_{\mathrm{L}} \mathrm{C}$, and those in the $\mathrm{HC}$ as ${ }_{\mathrm{L}} \mathrm{T}_{\mathrm{H}} \mathrm{C}$ and ${ }_{\mathrm{H}} \mathrm{T}_{\mathrm{H}} \mathrm{C}$, respectively. As above, we assume that both the LT and HT components in PThD consist of a low-coercivity and a high-coercivity component, respectively. Here, too, we can express the low- and the high-coercivity component in the LT as ${ }_{L} T_{L} C$ and ${ }_{L} T_{H} C$, and those in the HT as ${ }_{H} T_{L} C$ and ${ }_{\mathrm{H}} \mathrm{T}_{\mathrm{H}} \mathrm{C}$, respectively. In the hybrid results, the component below $250{ }^{\circ} \mathrm{C}$ corresponds to the $\mathrm{LT}$ in $\mathrm{pThD}$, and the remaining two components from $250{ }^{\circ} \mathrm{C}$ to $15 \mathrm{mT}$ (blue arrow in Fig. 6f) and higher than $15 \mathrm{mT}$ (orange arrow in Fig. 6f) correspond to ${ }_{H} T_{L} C$ and ${ }_{H} T_{H} C$, respectively. The comparison between the hybrid and the pThD results (Fig. 6f, e) clearly shows that the HT component (green arrow in Fig. 6e) consists of the sum of ${ }_{H} T_{L} C$ and ${ }_{H} T_{H} C$ (dashed blue and orange arrows in Fig. 6e), indicating that the HT component includes the ${ }_{H} \mathrm{~T}_{\mathrm{L}} \mathrm{C}$ component as a secondary magnetization. The ${ }_{H} \mathrm{~T}_{\mathrm{L}} \mathrm{C}$ component is not able to be separated by the pThD method alone since the spectrum of unblocking temperature of ${ }_{H} T_{L} C$ is comparable with that of the ${ }_{H} T_{H} C$ component, which probably corresponds to the primary magnetization.

In the reversals test, if the ChRMs indicating reversed polarity are distributed symmetrically with those indicating normal polarity, the ChRMs can be treated as a primary paleomagnetic record without any secondary component. For the reversals test, we used all the ChRMs, excluding the intervals of the reversal boundaries and the lower normal polarity zone (40-47 m), where the RPIs indicate much lower than the average value. In Fig. 7a, the $\alpha 95$ circle of reversed polarity ChRMs does not overlap with the $\alpha 95$ of normal polarity, indicating that the secondary components are not removed from the pAFD results. The same results are observed for pThD in Fig. $7 \mathrm{~b}$. This situation, whereby both pAFD and pThD failed to remove the secondary components, was also observed in the lower Chikura Group (Okada et al. 2012). In contrast, the hybrid result (Fig. 7c) shows that the $\alpha 95$ of reversed polarity includes the average of the normal polarity, and vice versa, which indicates that the ChRMs deduced by the hybrid method can be treated as the primary paleomagnetic record with a level of significance of $5 \%$ or less. This result indicates, for the first time, that the hybrid method is statistically confirmed to be able to successfully remove the secondary components since Okada et al. (2017), which did not conduct any field tests, including the reversals test. This result also indicates that the interpretation that the ${ }_{\mathrm{H}} \mathrm{T}_{\mathrm{H}} \mathrm{C}$ corresponds to the primary magnetization is proven.

According to the results of the hybrid method (Fig. 7c), we calculated the average declination value and the associated $\alpha 95$ interval of the hybrid ChRMs as $8.6 \pm 3.3^{\circ}$, indicating that a clockwise tectonic rotation of $\sim 10^{\circ}$ occurred in the KJ route region, which is similar to the results of a previous study (Kotake et al. 1995). We subtracted this value from the declinations to remove the rotation effect for subsequently determining the VGPs. All the ChRM directions, MADs, VGP latitudes, and RPIs, which were 


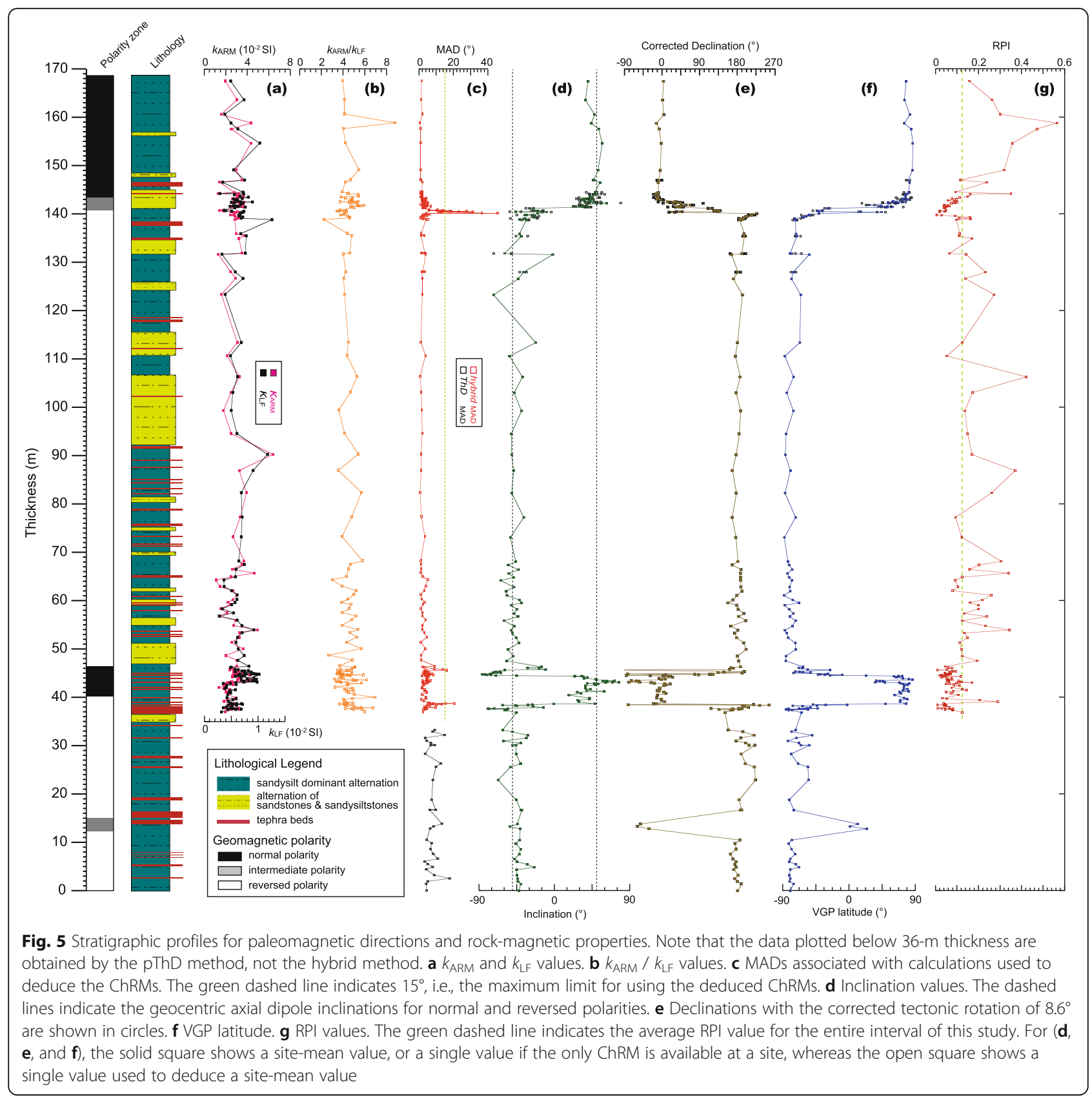

used following the discussion of geomagnetic field variations, were deduced by the hybrid method, which was conducted for all horizons above $36 \mathrm{~m}$ (Fig. 5c-g). However, we also plotted the ChRM directions, MADs, and VGP latitudes deduced by the pThD below $36 \mathrm{~m}$ as reference data (Fig. $5 \mathrm{c}-\mathrm{f}$ ). The ChRM inclinations are in close agreement with the expected values for the geocentric axial dipole (dashed lines in Fig. 5d). The MADs generally remain below $5^{\circ}$, while they exhibit much higher values in some intervals, mainly associated with geomagnetic reversals. We avoided using ChRMs with MADs greater than $15^{\circ}$ (Fig. 5c) in the subsequent discussion.

\section{Magnetostratigraphy}

The VGP latitudes plotted in Fig. $5 f$ indicate that two normal polarity zones are identified in the stratigraphic intervals above $142 \mathrm{~m}$ and between 38.6 and $44.6 \mathrm{~m}$, respectively. An intermediate polarity zone identified from 12 to $15 \mathrm{~m}$ will be discussed in a future study after applying the hybrid method. Kotake et al. (1995) reported that the Olduvai subchronozone was identified in the middle part of the Hata Formation, and a marker tephra bed named the KO tephra was intercalated in the Olduvai interval (Fig. 1e). The KO tephra is described as HF tephra in Kawakami and Shishikura (2006). They 


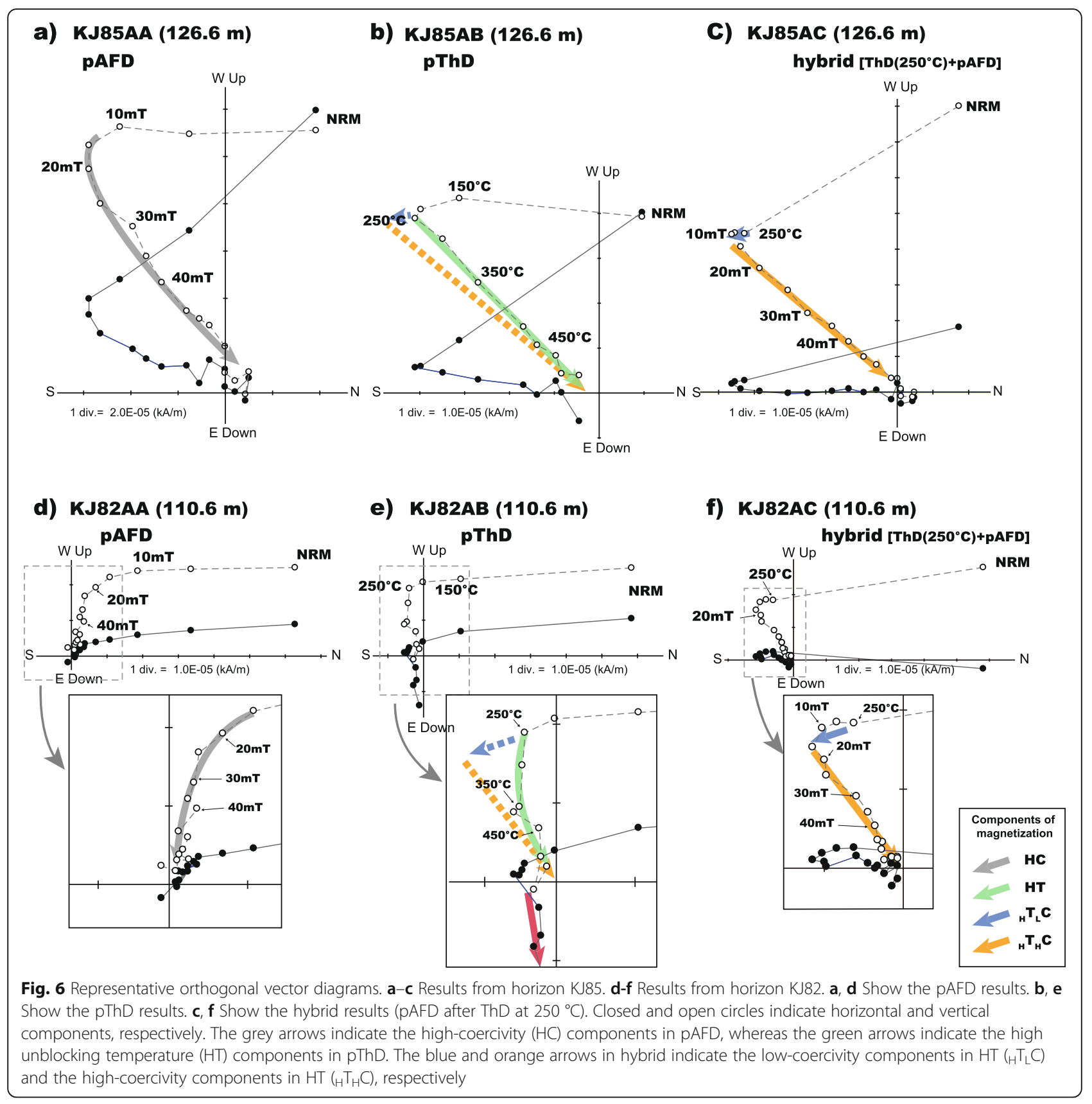

reported that the HF tephra was identified on a horizon slightly above the interval of this study. On the other hand, Okada et al. (2012) reported that the Gauss/ Matuyama boundary was identified in the Minamiasai Formation, which is just below the Hata Formation. These observations confirm that the upper and lower normal polarity zones identified in this study correspond to the Olduvai and Réunion subchronozones, respectively. The average sedimentation rates between the lower Réunion boundary at $39.3 \mathrm{~m}$ and upper Réunion boundary at 44.6 $\mathrm{m}$, and between the lower Olduvai boundary at $142.0 \mathrm{~m}$ and the upper Réunion boundary, are calculated as 25 $\mathrm{cm} / \mathrm{ky}$ and $57 \mathrm{~cm} / \mathrm{ky}$ respectively, using boundary ages of $2137 \mathrm{ka}$ and $2116 \mathrm{ka}$ for the lower and upper Réunion, respectively (Channell et al. 2016), and 1945 ka for the lower Olduvai (Ogg 2012). Since these sedimentation rates are higher than those in any deep-sea core (e.g., Channell et al. 2002, 2016; Valet et al. 2014), this sedimentary sequence has the potential to provide a paleomagnetic record that will play an important role in finding unknown field behaviors during the geomagnetic reversals.

In addition, we found a very characteristic tephra bed, in which cummingtonite is exclusively predominant among the heavy minerals, at the $43.55 \mathrm{~m}$ horizon that is $1 \mathrm{~m}$ 


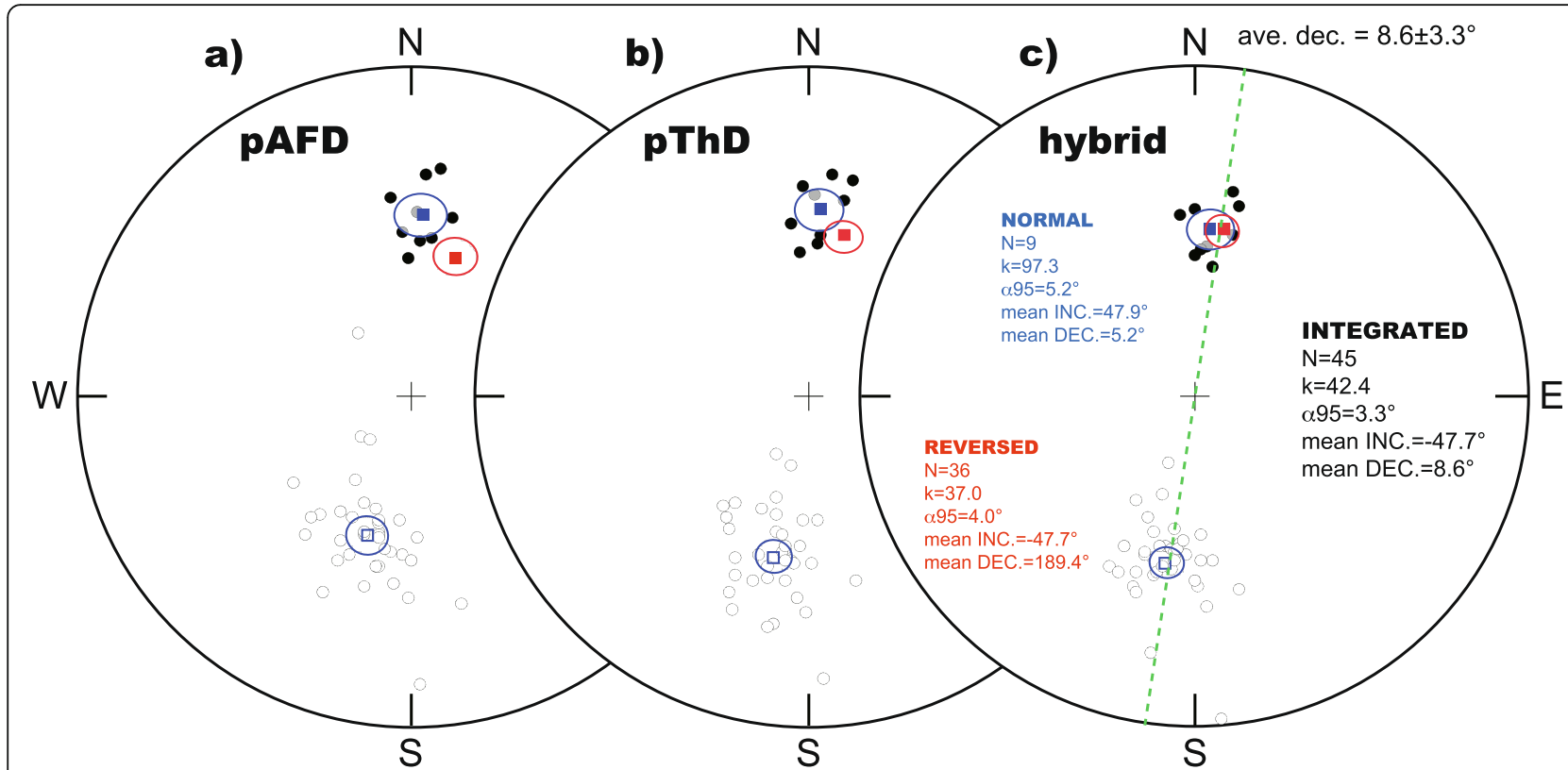

Fig. 7 Reversals test results. The equal-area stereo-net diagrams (a-c) show the ChRMs from the pAFD, pThD, and hybrid treatments, respectively. Closed and open circles indicate projections on the lower and upper hemispheres, respectively. The blue closed and open squares indicate the average directions of ChRMs on the lower and upper hemisphere, respectively. The blue circle indicates the 95\% confidence limits (a95) of each average direction. The red closed square and the surrounding circle indicate the symmetric average direction and its a95 on the lower hemisphere, which are transposed from those on the upper hemisphere in each diagram. The green dashed line on the right diagram indicates the average declination of all the ChRMs, excluding the intervals of the reversal boundaries and the lower normal polarity zone (40-47 m), where the RPIs indicate much lower than the average value

below the upper Réunion boundary (see S. Figure 1). This tephra bed could be useful as a local marker tephra bed to indicate a horizon of the upper Réunion boundary.

\section{Variations of VGP and RPI during the reversals}

The VGP paths, latitudes, and RPIs between 36 and 47 $\mathrm{m}$, which cover the entire Réunion subchronozone, are shown in Fig. $8 \mathrm{a}-\mathrm{c}$, respectively. In the same manner, those for the Réunion subchron from ODP Site 981 (Channell et al. 2003) are shown in Fig. 8d-f as a corresponding record. The VGPs of this study passed across the equator within a similar longitudinal band over Africa during both the upper and lower Réunion reversals, which is also observed in the Site 981 record, although the longitude is different (Fig. 8d). Moreover, the VGPs of this study settled in a VGP cluster area around China, termed "A" in this study (Fig. 8a) and is identified between 43.0 and $43.5 \mathrm{~m}$ immediately below the upper boundary (Fig. 8b). A similar cluster area with the same timing, but on a different longitudinal band from this study, is also observed in the Site 981 record (marked "A" in Fig. 8d, e). These observations suggest that these two records might reflect the nondipole feature of the geodynamo during the Réunion subchron. The VGPs in this study settled in a VGP cluster area around Argentina during the upper boundary reversal, termed "B" in this study (Fig. 8a, b). However, this is not apparent in Site 981 (Fig. 8d). In Fig. 8c, although the RPI values indicate minima at both the upper and lower Réunion boundaries, the RPI values for the entire Réunion interval are generally lower than the average of the entire interval of this study (Fig. 5g). This observation suggests that the dipole moment during the Réunion subchron never recovered to the average level after the first reversal ended, which was also observed in the RPI record from deep-sea sediments of the North Atlantic Ocean (Channell et al. 2016; Channell et al. 2020), and authigenic ${ }^{10} \mathrm{Be} /{ }^{9} \mathrm{Be}$ record from a deep-sea core of the western Pacific Ocean (Simon et al. 2018).

In the same manner in Fig. 8, we show our record from the stratigraphic interval between 138 and $145 \mathrm{~m}$ covering the lower Olduvai reversal in Fig. $9 \mathrm{a}-\mathrm{c}$, and the Site 984 record (Channell et al. 2002, 2013a, 2013b) in Fig. 9d-f. In the lower Olduvai polarity transition, the VGP did not move across the equator within a narrow longitudinal band, unlike in the Réunion subchron, but instead settled in several VGP cluster areas. The VGP can be observed in three areas (Fig. 9a): (A) the southern Indian Ocean, (B) North America, and (C) the southern South Pacific Ocean off South America. The VGP moved rapidly between these clusters. The RPI started to decline at $139.4 \mathrm{~m}$ immediately before the onset of the paleomagnetic directional change, where the VGP settled in cluster A in the southern hemisphere 


\section{This study}

(a) VGP path

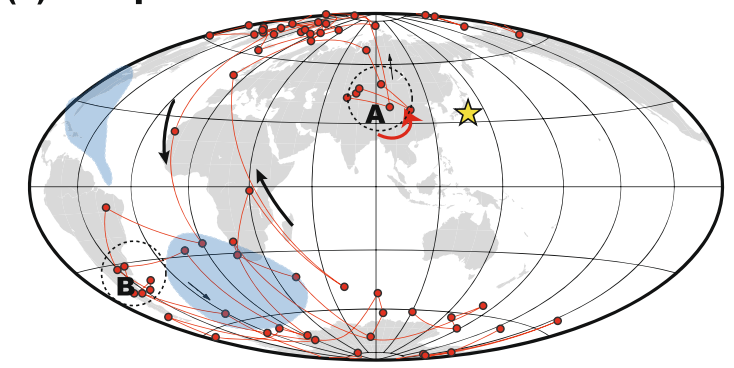

(b) VGP latitude ( ${ }^{\circ}$ )

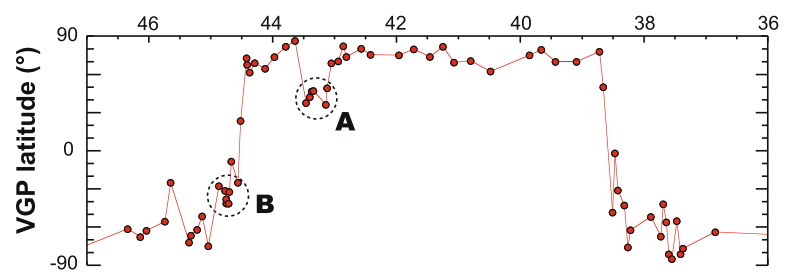

(c) RPI

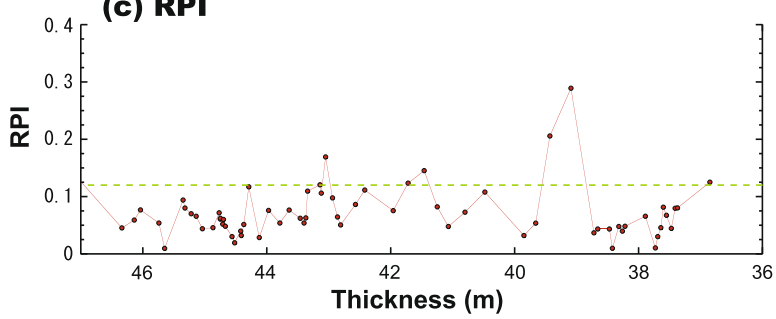

ODP Site 981

(d) VGP path

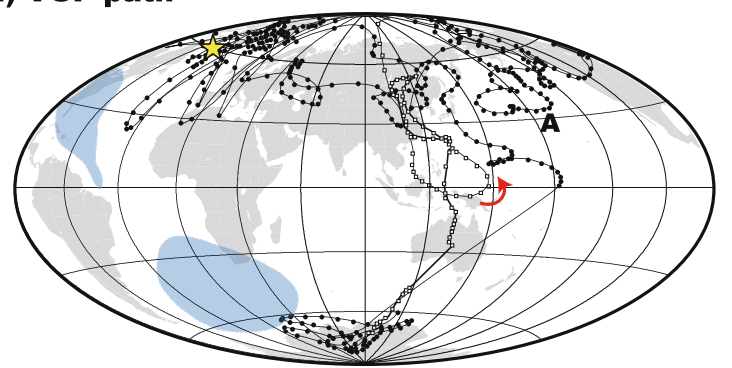

(e) VGP latitude $\left({ }^{\circ}\right)$

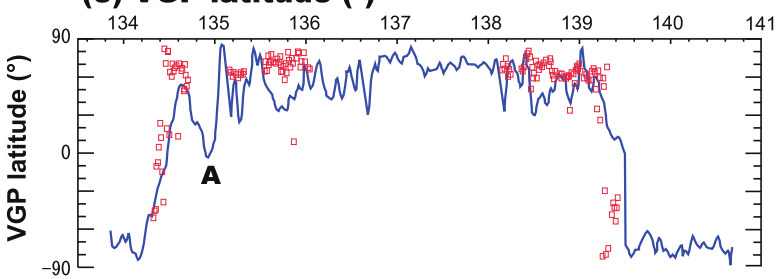

(f) RPI

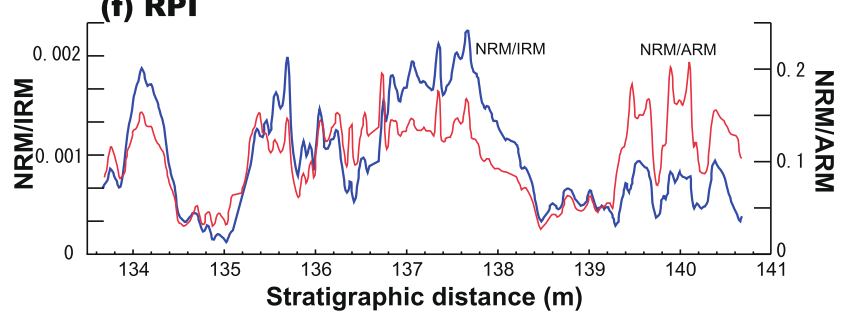

Fig. 8 VGP paths and horizontal plots of the VGP latitude and RPI covering the Réunion subchron that correlates with a North Atlantic record. ac Show the results of this study. $\mathbf{d}-\mathbf{f}$ Show the results from ODP Site 981 (Channell et al. 2003). The letter "A" and "B" in (a) and (b), and "A" in (d) and (e) indicate parts of the characteristic VGP clusters identified on (a) and (d), respectively. The blue shaded areas in (a) and (d), indicate that the vertical component of the NAD field at the Earth's surface is less than - $15 \mu$ T (Constable 2007). The yellow stars indicate the sample/core sites. The green dashed line in (c) indicates the average RPI value for the entire interval of this study

(Fig. 9b, c). Immediately following this, the RPI declined rapidly, reaching a minimum at $140.1 \mathrm{~m}$, which corresponds to the VGP settling in cluster B in the northern hemisphere. Subsequently, the RPI gradually recovered to a peak at $144.2 \mathrm{~m}$. During this recovery, the VGP settled in cluster $\mathrm{C}$ in the southern hemisphere at approximately $141 \mathrm{~m}$, before moving back again to cluster B in the northern hemisphere.

Similar features to these, particularly for the asymmetric RPI profile consisting of a rapid decline and slow recovery and the locations of the VGP cluster areas, are well documented in the Site 984 record (Channell et al. 2002, 2013a, 2013b) shown in Fig. 9d-f. The cluster areas $\mathrm{A}, \mathrm{B}$, and $\mathrm{C}$ are observed in almost the same locations in both records. Similar VGP cluster areas have also been identified in lava records (e.g., Hoffman 1991, 1992) as well as other sedimentary records (e.g., Channell et al. 2002; Kusu et al. 2016). These cluster positions have been discussed to be related to the vertical flux patches in the present non-axial dipole (NAD) field (e.g.,
Channell et al. 2003, 2004; Hoffman et al. 2008). Kusu et al. (2016) reported that the VGP cluster areas in the upper Olduvai boundary were observed in similar locations to downward flux patches of the NAD, which occur in North America and the southern South Pacific, where the vertical component is less than $-15 \mu \mathrm{T}$ according to the average geomagnetic field for the past 400 years (Constable 2007). The locations of these flux patches of the NAD correlate relatively well with our record, especially for cluster $B$ in the Réunion subchron and clusters A and B in the lower Olduvai reversal, which suggests that the VGPs during geomagnetic reversals associated with low RPIs were strongly affected by the NAD field.

\section{Conclusions}

This study presented a reliable paleomagnetic record that passed the reversals test for the lower Matuyama chronozone, which includes the Réunion subchronozone and the lower Olduvai polarity reversal from a 


\section{This study}

\section{(a) VGP path}

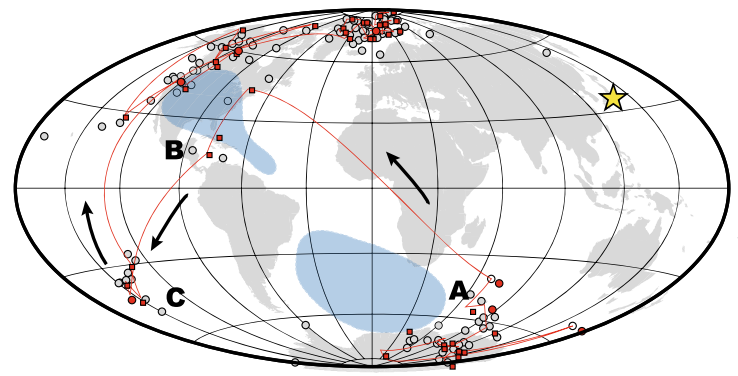

(b) VGP latitude $\left({ }^{\circ}\right)$

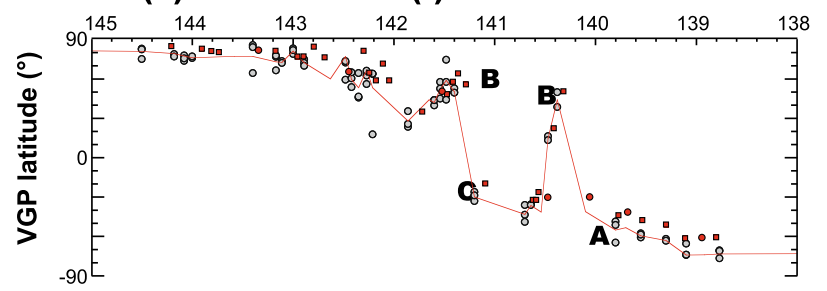

(c) RPI

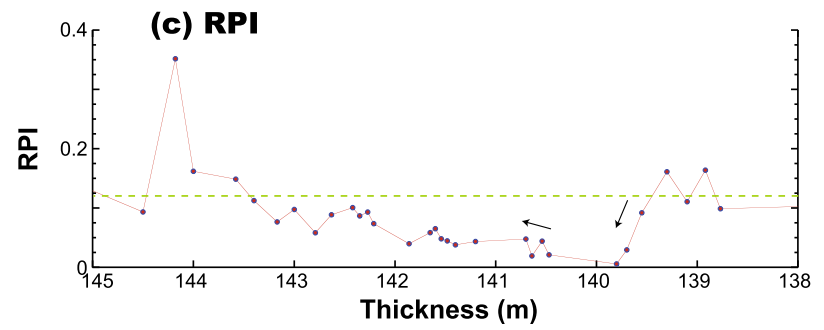

ODP Site 984

(d) VGP path

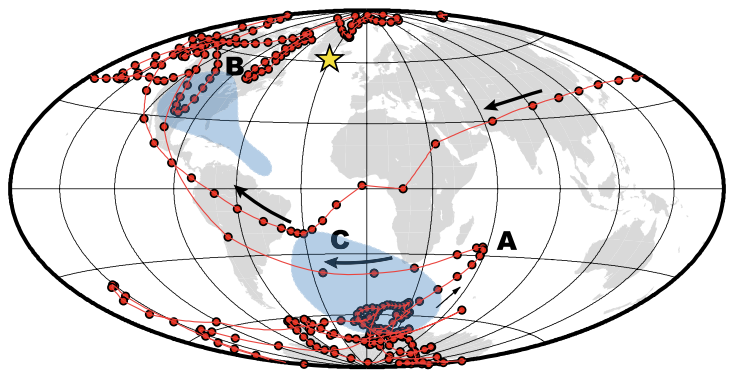

(e) VGP latitude $\left({ }^{\circ}\right)$
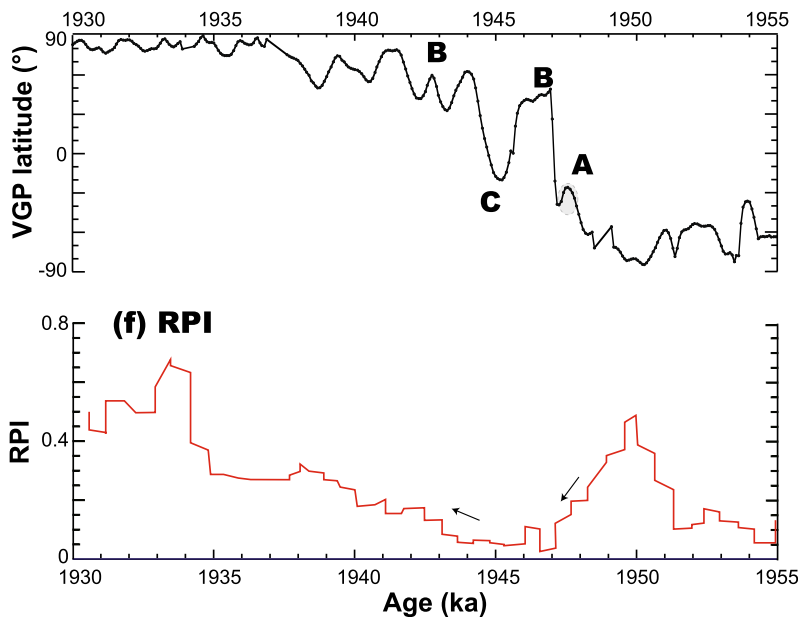

Fig. 9 VGP paths and horizontal plots of the VGP latitude and RPI covering the Olduvai bottom reversal of this study correlated with a North Atlantic record. a-c Show the results of this study. d-f Show the results from ODP Site 984 (Channell et al. 2002, 2013a, 2013b). Letters "A" to "C" in (a) and (b) and (d) and (e) indicate the locations of the characteristic VGP clusters identified on (a) and (d), respectively. The blue shaded areas in (a) and (d) indicate that the vertical component of the NAD field at the Earth's surface is less than - $15 \mu$ T (Constable 2007). The yellow stars indicate the sample/core sites. The green dashed line in (c) indicates the average RPI value for the entire interval of this study. The red square shows the site mean value at a site in (a) and (b) if multiple ChRMs are available at a site. The grey circle in (a) and (b) shows a single value used to deduce a site-mean value, while the red circle in (a) and (b) shows a representative value at a site if a single ChRM is only available at a site. The lines are connected among the red squares or the red circles

continuous section along the KJ route, with a stratigraphic thickness of $168 \mathrm{~m}$. In this section, the Réunion subchronozone and lower Olduvai reversal were identified at $38.6-44.6 \mathrm{~m}$ and $142 \mathrm{~m}$, respectively. The average sedimentation rates between the lower and upper Réunion boundaries and between the upper Réunion boundary and the lower Olduvai boundary were $25 \mathrm{~cm} / \mathrm{ky}$ and $57 \mathrm{~cm} / \mathrm{ky}$, respectively, whose sedimentation rates are higher than those recorded in any deep-sea core. The VGP at both the upper and lower Réunion boundaries passed across the equator within a similar longitudinal band over Africa. Immediately below the upper boundary, between 43.0 and $43.5 \mathrm{~m}$, the VGP settled in a cluster area around China. Additionally, the RPI values for the entire Réunion interval were generally lower than the average of the entire interval of this study.
Conversely, the VGP for the lower Olduvai reversal boundary did not pass across the equator within a narrow longitudinal band and instead settled in several cluster areas, i.e., the southern Indian Ocean, North America, and the southern South Pacific Ocean off South America. The VGP then moved rapidly between these clusters. The RPI declined rapidly and recovered slowly as the VGP moved rapidly between the cluster areas. The geomagnetic reversal features observed in our record might be affected by the NAD field. The ongoing study, which is for an oxygen isotopic analysis of fossil foraminiferal tests from this formation, will provide us a reliable age model for the section along the KJ route. That will facilitate a further discussion on the timings and durations of the individual geomagnetic field variations during the polarity reversals observed in this study. 


\section{Supplementary information}

Supplementary information accompanies this paper at https://doi.org/10. 1186/s40645-020-00352-0.

Additional file 1:. Figure S1. Detailed geologic column and sampling horizons for the geomagnetic reversal intervals; i.e., a: the upper and lower boundaries of the Réunion subchronozone, b: the lower boundary of the Olduvai subchronozone.

Additional file 2:. Table S1. Paleomagnetic and rock-magnetic results for the specimens after the hybrid treatment. Note that the results of the specimens below $36 \mathrm{~m}$, after the pThD treatment, are not shown in this table.

\section{Abbreviations}

AFD: Alternating field demagnetization; ARM: Anhysteretic remanent magnetization; pDRM: Post-depositional remanent magnetization; IRM: Isothermal remanent magnetization; MAD: Maximum angular deviation; M-B boundary: Matsuyama-Brunhes boundary; MIS: Marine isotope stage; NAD: Non-axial dipole; NRM: Natural remanent magnetization; RPI: Relative paleointensity; ThD: Thermal demagnetization; VGP: Virtual geomagnetic

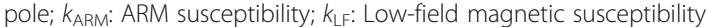

\section{Acknowledgements}

We thank Toru Maruoka for collecting the paleomagnetic samples and helping with the paleomagnetic measurements. We also thank Prof. Yuhji Yamamoto, who supported the rock-magnetic measurements at the Center for Advanced Marine Core Research, Kochi University through a joint-use system (Grants 16A023/16B021, and 17A038/17B038). We want to thank the editor, Prof. Ryuji Tada, and the anonymous reviewers for their constructive comments, and Editage (www.editage.com) for English language editing.

\section{Availability of data and material}

Please contact the author for data requests.

\section{Authors' contributions}

TK performed the experimental study, analyzed the data, and helped prepare the manuscript. MO proposed the topic, designed the study, analyzed the data, and wrote the manuscript. Both authors read and approved the final manuscript.

\section{Authors' information}

TK is an employee of Yachiyo Engineering Co., Ltd., Japan. This study is based on part of his Master thesis at Ibaraki University. MO was the supervisor of TK and a professor at Ibaraki University, Japan.

\section{Funding}

This study was supported by JSPS KAKENHI grants (16H04068 and 19H00710) awarded to $\mathrm{MO}$

\section{Competing interests}

The authors declare that they have no competing interests.

\section{Author details}

${ }^{1}$ Yachiyo Engineering Co., Ltd., Tokyo, Japan. ${ }^{2}$ Department of Earth Sciences, Ibaraki University, 2-2-1 Bunkyo, Mito, Ibaraki 310-8512, Japan.

Received: 1 November 2019 Accepted: 15 July 2020

Published online: 08 August 2020

\section{References}

Amit H, Leonhardt R, Wicht J (2010) Polarity reversals from paleomagnetic observations and numerical dynamos simulations. Space Sci Rev 155:293-335 https://doi.org/10.1007/s11214-010-9695-2

Bowles JA, Jackson MJ, Berquo TS, Sølheid PA, Gee JS (2013) Inferred time- and temperature-dependent cation ordering in natural titanomagnetites. Nat Commun 4:1916 https://doi.org/10.1038/ncomms2938

Channell JET (2017) Complexity in Matuyama-Brunhes polarity transitions from North Atlantic IODP/ODP deep-sea sites. Earth Planet Sci Lett 467:43-56 https://doi.org/10.1016/j.epsl.2017.03.019
Channell JET, Mazaud A, Sullivan P, Turner S, Raymo ME (2002) Geomagnetic excursions and paleointensities in the Matuyama Chron at Ocean Drilling Program Sites 983 and 984 (Iceland Basin). J Geophys Res 107(B6) https://doi. org/10.1029/2001JB000491

Channell JET, Labs J, Raymo ME (2003) The Réunion Subchronozone at ODP Site 981 (Feni Drift, North Atlantic). Earth Planet Sci Lett 215(1):1-12 https://doi. org/10.1016/S0012-821X(03)00435-7

Channell JET, Curtis JH, Flower BP (2004) The Matuyama-Brunhes boundary interval (500-900 ka) in North Atlantic drift sediments. Geophys J Int 158(2): 489-505 https://doi.org/10.1111/j.1365-246X.2004.02329.x

Channell JET, Xuan C, Hodell DA (2009) Stacking paleointensity and oxygen isotope data for the last 1.5 Myr (PISO-1500). Earth Planet Sci Lett 283(1):1423 https://doi.org/10.1016/j.epsl.2009.03.012

Channell JET, Mazaud A, Sullivan P, Turner S, Raymo ME (2013a) Paleointensity of ODP Site 162-984. PANGAEA. https://doi.org/10.1594/PANGAEA.809435

Channell JET, Mazaud A, Sullivan P, Turner S, Raymo ME (2013b) Declination and inclination of ODP Site 162-984. PANGAEA. https://doi.org/10.1594/PANGAEA. 809436

Channell JET, Hodell DA, Curtis JH (2016) Relative paleointensity (RPI) and oxygen isotope stratigraphy at IODP Site U1308: North Atlantic RPI stack for 1.2-2.2 Ma (NARPI-2200) and age of the Olduvai Subchron. Quat Sci Rev 131:1-19 https://doi.org/10.1016/j.quascirev.2015.10.011

Channell JET, Singer BS, Jicha BR (2020) Timing of Quaternary geomagnetic reversals and excursions in volcanic and sedimentary archives. Quat Sci Rev 228:106114 https://doi.org/10.1016/j.quascirev.2019.106114

Constable C (2007) Non-dipole field. In: Gubbins D, Herrero-Bervera E (eds) Encyclopedia of geomagnetism and paleomagnetism. Springer, Netherlands, pp 701-704

Day R, Fuller M, Schmidt VA (1977) Hysteresis properties of titanomagnetites: grain size and composition dependence. Phys Earth Planet Inter 13(4):260267 https://doi.org/10.1016/0031-9201(77)90108-X

Dunlop DJ (2002) Theory and application of the Day plot (Mrs/Ms versus Hcr/Hc), 1. Theoretical curves and tests using titanomagnetite data. J Geophys Res 107(B3) https://doi.org/10.1029/2001JB000486

Haneda Y, Okada M (2019) Pliocene integrated chronostratigraphy from the Anno Formation, Awa Group, Boso Peninsula, central Japan, and its paleoceanographic implications. Prog Earth Planet Sci 6:6 https://doi.org/10 1186/s40645-018-0248-8

Haneda Y, Okada M, Kubota Y, Suganuma Y (2020) Millennial-scale hydrographic changes in the northwestern Pacific during marine isotope stage 19: Teleconnection with ice melt in the North Atlantic. Earth Planet Sci Lett 531: 115936 https://doi.org/10.1016/j.epsl.2019.115936

Hoffman KA (1991) Long-lived transitional states of the geomagnetic field and the two dynamo families. Nature 354(6351):273-277

Hoffman KA (1992) Dipolar reversal states of the geomagnetic field and coremantle dynamics. Nature 359(6398):789-794

Hoffman KA, Singer BS, Camps P, Hansen LN, Johnson KA, Clipperton S, Carvallo C (2008) Stability of mantle control over dynamo flux since the midCenozoic. Phys Earth Planet Inter 169(1):20-27 https://doi.org/10.1016/j.pepi. 2008.07.012

Hunt CP, Moskowitz BM, Banerjee SK (1995) Magnetic properties of rock and mineral. In: Thomas JA (ed) Rock physics and phase relations: a handbook of physical constant. American Geophysical Union, Washington DC, p 236

Ingham M, Turner G (2008) Behaviour of the geomagnetic field during the Matuyama-Brunhes polarity transition. Phys Earth Planet Inter 168:163-178 https://doi.org/10.1016/j.pepi.2008.06.008

Jarboe NA, Coe RS, Glen JMG (2011) Evidence from lava flows for complex polarity transitions: the new composite Steens mountain reversal record. Geophys J Int 186(2):580-602 https://doi.org/10.1111/j.1365-246X.2011.05086.x

Kameo K, Okada M (2016) Calcareous nannofossil biochronology from the upper Pliocene to lower Pleistocene in the southernmost Boso Peninsula, central part of the Pacific side of Japan. J Asian Earth Sci 129:142-151 https://doi. org/10.1016/j.jseaes.2016.08.003

Kawakami S, Shishikura M (2006) Geology of the Tateyama District. Quadrangle Series, 1:50,000, Geological Survey of Japan, AIST, 82 p. (in Japanese with English abstract).

Kazaoka O, Suganuma Y, Okada M, Kameo K, Head MJ, Yoshida T, Sugaya M, Kameyama S, Ogitsu I, Nirei H, Aida N, Kumai H (2015) Stratigraphy of the Kazusa Group, Chiba Peninsula, Central Japan: an expanded and highlyresolved marine sedimentary record from the Lower and Middle Pleistocene. Quat Int 383:116-134 https://doi.org/10.1016/j.quaint.2015.02.065 
Kirschvink JL (1980) The least-squares line and plane and the analysis of palaeomagnetic data. Geophys J R Astron Soc 62(3):699-718 https://doi.org/ 10.1111/j.1365-246X.1980.tb02601.x

Kotake N (1988) Upper Cenozoic marine sediments in southern part of the Boso Peninsula, central Japan. J Geol Soc Jpn 94:187-206 https://doi.org/10.5575/ geosoc.94.187 (in Japanese with English abstract)

Kotake N, Koyama M, Kameo K (1995) Magnetostratigraphy and biostratigraphy of the Plio-Pleistocene Chikura and Toyofusa Groups, southernmost part of the Boso Peninsula, central Japan. J Geol Soc Jpn 101:515-531 https://doi. org/10.5575/geosoc.101.515 (in Japanese with English abstract)

Kusu C, Okada M, Nozaki A, Majima R, Wada H (2016) A record of the upper Olduvai geomagnetic polarity transition from a sediment core in southern Yokohama City, Pacific side of central Japan. Prog Earth Planet Sci 3:26 https://doi.org/10.1186/s40645-016-0104-7

Merrill RT, McFadden PL (1999) Geomagnetic polarity transitions. Rev Géogr Physique 37(2):201-226

Mitsunashi T, Suda Y (1980) The geological map of Japan, scale 1:200000, Otaki. Geol Surv Japan, Tsukuba

Naruse Y, Sugimura A, Koike K (1951) Geology of Tertiary in southernmost part of the Boso Peninsula. Japan J Geol Soc Jpn 57:511-526 https://doi.org/10. 5575/geosoc.57.511 (in Japanese)

Niitsuma N (1971) Detailed study of the sediments recording the Matuyama-Brunhes geomagnetic reversal. Tohoku Univ Sci Rep 2nd Ser (Geol) 43:1-39

Niitsuma N (1976) Magnetic stratigraphy in the Boso Peninsula. J Geol Soc Jpn 82:163-181 (in Japanese with English abstract)

Nishida N, Kazaoka O, Izumi K, Suganuma Y, Okada M, Yoshida T, Ogitsu I, Nakazato H, Kameyama S, Kagawa A, Morisaki M, Nirei N (2016) Sedimentary processes and depositional environments of a continuous marine succession across the Lower-Middle Pleistocene boundary: Kokumoto Formation, Kazusa Group, central Japan. Quat Int 397:3-15 https://doi.org/10.1016/j.quaint.2015.06.045

Oda M (1977) Planktonic foraminiferal biostratigraphy of the Late Cenozoic sedimentary sequences, Central Honshu, Japan. In: Science reports of Tohoku University, 2nd series (geology), vol 48, pp 1-72

Ogg JG (2012) Geomagnetic polarity time scale. In: Gradstein FM, Ogg JG, Schmitz MD, Ogg GM (eds) The geologic time scale 2012, vol 1. Elsevier, Boston, p 435

Okada M, Niitsuma N (1989) Detailed paleomagnetic records during the Brunhes-Matuyama geomagnetic reversal and a direct determination of depth lag for magnetization in marine sediments. Phys Earth Planet Inter 56: 133-150 https://doi.org/10.1016/0031-9201(89)90043-5

Okada M, Tokoro Y, Uchida Y, Arai Y, Saito K (2012) An integrated stratigraphy around the Plio-Pleistocene boundary interval in the Chikura Group, southernmost part of the Boso Peninsula, central Japan, based on data from paleomagnetic and oxygen isotopic analyses. J Geol Soc Jpn 118:97-108 https://doi.org/10.5575/geosoc.2011.0027 (in Japanese with English abstract)

Okada M, Suganuma Y, Haneda Y, Kazaoka O (2017) Paleomagnetic direction and paleointensity variations during the Matuyama-Brunhes polarity transition from a marine succession in the Chiba composite section of the Boso Peninsula, central Japan. Earth, Planets, Space 69:45 https://doi.org/10.1186/ s40623-017-0627-1

Özdemir Ö, Dunlop DJ (2010) Hallmarks of maghemitization in low-temperature remanence cycling of partially oxidized magnetite nanoparticles. J Geophys Res 115:B02101 https://doi.org/10.1029/2009JB006756

Özdemir Ö, Dunlop DJ, Moskowitz BM (1993) The effect of oxidation on the Verwey transition in magnetite. Geophys Res Lett 20:1671-1674 https://doi. org/10.1029/93GL01483

Roberts AP, Winklhofer M (2004) Why are geomagnetic excursions not always recorded in sediments? Constraints from post-depositional remanent magnetization lock-in modelling. Earth Planet Sci Lett 227:345-359 https:// doi.org/10.1016/j.epsl.2004.07.040

Roberts AP, Chang L, Rowan CJ, Horng CS, Florindo F (2011) Magnetic properties of sedimentary greigite (Fe3S4): An update. Rev Geophys 49:RG1002 https:// doi.org/10.1029/2010RG000336

Roberts AP, Almeida TP, Church NS, Harrison RJ, Heslop D, Li Y, Muxworthy AR, Williams W, Zhao X (2017) Resolving the origin of pseudo-single domain magnetic behavior. J Geophys Res Solid Earth 122:9534-9558 https://doi.org/ 10.1002/2017JB014860

Roberts AP, Tauxe L, Heslop D, Zhao X, Jiang Z (2018) A Critical Appraisal of the "Day" Diagram. J Geophys Res Solid Earth 123:2618-2644 https://doi.org/10. 1002/2017JB015247
Sato T, Takayama T, Kato M, Kudo T, Kameo K (1988) Calcareous microfossil biostratigraphy of the uppermost Cenozoic formations distributed in the coast of the Japan Sea, Part 4: conclusion. Journal of the Japanese Association for Petroleum Technology 53:474-491 (in Japanese with English abstract)

Simon Q, Bourlès DL, Thouveny N, Horng C-S, Valet J, Bassinot F, Choy S (2018) Cosmogenic signature of geomagnetic reversals and excursions from the Réunion event to the Matuyama-Brunhes transition (0.7-2.14 Ma interval). Earth Planet Sci Lett 482:510-524 https://doi.org/10.1016/j. epsl.2017.11.021

Simon Q, Suganuma Y, Okada M, Haneda Y, ASTER team (2019) Highresolution ${ }^{10} \mathrm{Be}$ and paleomagnetic recording of the last polarity reversal in the Chiba composite section: Age and dynamics of the MatuyamaBrunhes transition. Earth Planet Sci Lett 519: 92-100. https://doi.org/10. 1016/j.epsl.2019.05.004

Suganuma Y, Yamazaki T, Kanamatsu T, Hokanishi N (2008) Relative paleointensity record during the last $800 \mathrm{ka}$ from the equatorial Indian Ocean: implication for relationship between inclination and intensity variations. Geochem Geophys Geosyst 9:Q02011 https://doi.org/10.1029/ 2007 GC001723

Suganuma Y, Okuno J, Heslop D, Roberts AP, Yamazaki T, Yokoyama Y (2011) Post-depositional remanent magnetization lock-in for marine sediments deduced from ${ }^{10} \mathrm{Be}$ and paleomagnetic records through the MatuyamaBrunhes boundary. Earth Planet Sci Lett 311:39-52 https://doi.org/10.1016/j. epsl.2011.08.038

Suganuma Y, Okada M, Horie K, Kaiden H, Takehara M, Senda R, Kimura J, Kawamura K, Haneda Y, Kazaoka O, Head MJ (2015) Age of MatuyamaBrunhes boundary constrained by U-Pb zircon dating of a widespread tephra. Geology 43:491-494 https://doi.org/10.1130/G36625.1

Suganuma Y, Haneda Y, Kameo K, Kubota Y, Hayashi H, Itaki T, Okuda M, Head MJ, Sugaya M, Nakzato H, Igarashi A, Shikoku K, Hongo M, Watanabe M, Satoguchi Y, Takeshita Y, Nishida N, Izumi K, Kawamura K, Kawamata M, Okuno J, Yoshida T, Ogitsu I, Yabusaki H, Okada M (2018) Paleoclimatic and Paleoceanographic records of marine isotope stage 19 at the Chiba composite section, central Japan: a reference for the Early-Middle Pleistocene boundary. Quat Sci Rev 191: 406-430. https://doi.org/https://doi.org/10.1016/ j.quascirev.2018.04.022

Tamura I, Okada M, Mizuno K (2016) An integrated stratigraphy around the PlioPleistocene boundary in the Chikura Group, the Boso Peninsula, central Japan, based on data from paleomagnetic, oxygen isotopic and widespread tephra correlation. Geogr Rep Tokyo Metr Univ 51:41-52

Tatsumi Y, Tamura Y, Nichols ARL, Ishizuka O, Takeshita N, Tani K (2016) Izu-Bonin Arc. In: Moreno T, Wallis S, Kojima T, Gibbons W (eds) The geology of Japan. Geological Society, London

Tauxe $L$ (1993) Sedimentary records of relative paleointensity of the geomagnetic-field - theory and practice. Rev Geophys 31:319-354 https:// doi.org/10.1029/93RG01771

Unozawa A, Oka S, Sakamoto T (1983) The geological map of Japan, scale, 1: 200000, Chiba. Geoll Surv Japan, Tsukuba, In

Valet JP (2003) Time variations in geomagnetic intensity. Rev Geophys 41:1004 https://doi.org/10.1029/2001RG000104

Valet JP, Fournier A (2016) Deciphering records of geomagnetic reversals. Rev Geophys 54:410-446 https://doi.org/10.1002/2015RG000506

Valet JP, Meynadier L, Guyodo Y (2005) Geomagnetic dipole strength and reversal rate over the past two million years. Nature 435(7043):802-805

Valet JP, Fournier A, Courtillot V, Herrero-Bervera E (2012) Dynamical similarity of geomagnetic field reversals. Nature 490, 89-94. https://doi.org/10.1038/ nature 11491

Valet JP, Bassinot F, Bouilloux A, Bourlés DL, Nomade S, Guillou V, Lopes F, Thouveny N, Dewilde F (2014) Geomagnetic, cosmogenic and climatic changes across the last geomagnetic reversal from Equatorial Indian Ocean sediments. Earth Planet Sci Lett 397:67-79 https://doi.org/10.1016/j.epsl.2014.03.053

Valet JP, Meynadie L, Simon Q, Thouveny N (2016) When and why sediments fail to record the geomagnetic field during polarity reversals? Earth Planet. Sci Lett 453:96-107 https://doi.org/10.1016/j.epsl.2016.07.055

Verwey EJW (1939) Electronic conduction of magnetite (Fe3O4) and its transition point at low temperatures. Nature 144:327-328 https://doi.org/10.1038/ $144327 \mathrm{bo}$

Yamazaki T, loka N (1997) Cautionary note on magnetic grain-size estimation using the ratio of ARM to magnetic susceptibility. Geophys Res Lett 24(7): 751-754 https://doi.org/10.1029/97GL00602 
Yamazaki T, Oda H (2005) A geomagnetic paleointensity stack between 0.8 and

3.0 Ma from equatorial Pacific sediment cores. Geochem Geophys Geosyst 6(11):Q11H20 https://doi.org/10.1029/2005GC001001

Zijderveld JDA (1967) A.C. demagnetization of rocks: analysis of result. In:

Collinson DW, Creer KM, Runcorn SK (eds) Methods in paleomagnetism.

Elsevier, New York, pp 254-286

\section{Publisher's Note}

Springer Nature remains neutral with regard to jurisdictional claims in published maps and institutional affiliations.

Submit your manuscript to a SpringerOpen ${ }^{\circ}$ journal and benefit from:

- Convenient online submission

- Rigorous peer review

- Open access: articles freely available online

- High visibility within the field

- Retaining the copyright to your article

Submit your next manuscript at $\boldsymbol{\wedge}$ springeropen.com 